ГОВОРОВА К.I.

\author{
ДОКУМЕНТАЛЬНА ОБІРУНТОВАНІСТЬ ПРОВЕДЕННЯ \\ ФІНАНСОВО-КРЕДИТНИХ ОПЕРАЦІЙ ТА ВІДОБРАЖЕННЯ ЇХ \\ В ОБЛІКУ ПІДПРИЕМСТВА
}

\title{
DOCUMENTARY SUBSTANTIATION OF FINANCIAL AND CREDIT OPERATIONS AND THEIR REFLECTION IN THE ACCOUNTING OF THE ENTERPRISE
}

Метою статті є з'ясування сутності та значення документальної обгрунтованості проведення документів фінансово-кредитних операцій і відображення їх в обліку підприємства для експертного дослідження документів фінансово-кредитних операцій. У статті здійснено аналіз наукових і нормативно-правових джерел, що регламентують діяльність з надання фінансових послуг, та з'ясовано зміст фінансово-кредитних операцій і основних вимог до них. Встановлено, що умови та порядок здійснення фінансово-кредитних операцій, а також їх наслідки знаходять своє відображення в обліково-звітній документації. Зазначено, що фінансово-кредитні операції, будучи різновидом фінансових послуг, повинні бути документально обгрунтованими, а тому під час доказування у справах про правопорушення, пов'язані з фінансово-кредитними операціями, особлива увага приділяється пошуку та дослідженню документів таких операцій. Акцентовано, що особливу роль в цій діяльності відіграє такий різновид судової експертизи як судова економічна експертиза документів фінансово-кредитних операцій, оскільки основні ії завдання зводяться до визначення їх документальної обгрунтованості. Визначено сутність $і$ значення документальної обгрунтованості фінансово-кредитних операцій, а також їх відображення їх в обліку підприємства. 3'ясовано, що документальна обгрунтованість фінансово-кредитних операцій - це безперервне та повне фіксування інформації про здійснені фінансово-кредитні операції в обліково-звітній документації для узагальнення даних про діяльність суб'єкта господарювання та його фінансовий стан. Зроблено висновок, що визначення документальної обгрунтованості фінансово-кредитних операцій, як основного завдання судової економічної експертизи документів фінансово-кредитних операцій, полягає в дослідженні первинних документів, реєстрів бухгалтерського обліку, фінансової звітності, інших документів, пов'язаних із здійсненням фінансово-кредитних операцій і встановленні їх відповідності фактичним умовам здійснення фінансово-кредитних операцій і чинному законодавству України.

Ключові слова: документальна обтрунтованість, фінансово-кредитні операції, облік підприсмства, експертиза документів фінансово-кредитних операцій, завдання експертизи, об'єкт експертизи.

The purpose of the article is to clarify the essence and significance of the documentary validity of the documents of financial and credit transactions and their reflection in the accounting of the enterprise for expert study of documents of financial and credit transactions. The article analyzes the scientific and regulatory sources governing the provision of financial services, and clarifies the content of financial and credit transactions and the basic requirements for them. It is established that the conditions and procedure for financial and credit transactions, as well as their consequences are reflected in the accounting documentation. It is stated that financial and credit transactions, as a kind of financial services, must be documented, and therefore, when proving in cases of offenses related to financial and credit transactions, special attention is paid to finding and researching docu-

(C) ГОВОРОВА К.І. - аспірант (Харківський науково-дослідний інститут судових експертиз ім. Засл. проф. М.С. Бокаріуса) 
ments of such transactions. It is emphasized that a special role in this activity is played by such a type of forensic examination as forensic economic examination of documents of financial and credit operations, as its main tasks are to determine their documentary validity. The essence and significance of documentary substantiation of financial and credit operations, as well as their reflection in the accounting of the enterprise are determined. It was found that the documentary validity of financial and credit transactions is a continuous and complete recording of information about financial and credit transactions in the accounting and reporting documentation to summarize data on the activities of the entity and its financial condition. It is concluded that determining the documentary validity of financial and credit transactions, as the main task of forensic economic examination of financial and credit transactions, is to study primary documents, accounting records, financial statements, other documents related to financial and credit transactions and establishing their compliance with the actual conditions of financial and credit operations and current legislation of Ukraine.

Key words: documentary substantiation, financial and credit operations, enterprise accounting, examination of documents of financial and credit operations, examination tasks, object of examination.

Постановка проблеми. Дуже часто в результаті кредитних правовідносин можуть виникати спори у зв'язку з визнанням недійсними кредитних договорів та договорів іпотеки, оскарження істотних змін умов кредитних договорів, реструктуризації проблемних кредитів, списання безнадійної заборгованості та ін. При вирішенні подібних спорів зазвичай не обійтись без проведення незалежної економічної експертизи. Експертиза кредитних правовідносин здійснюється 3 метою встановлення порушень банком або позичальником законодавства та умов кредитного договору. Дослідження включає в себе аналіз документів кредитних операцій банку і клієнта з метою визначення документальної обгрунтованості проведення фінансово-кредитних операцій [1, с. 9]. У зв'язку з чим важливо з'ясувати в чому полягає документальна обгрунтованість проведення фінансово-кредитних операцій, які документи й у якому обсязі необхідно надати судовому експертові для проведення судової економічної експертизи документів фінансово-кредитних операцій.

Аналіз останніх досліджень. У науковій літературі питання документальної обгрунтованості проведення фінансово-кредитних операцій та відображення їх в обліку підприємства, особливо в контексті визначення завдань судової економічної експертизи документів фінансово-кредитних операцій, не розглядалися. Тому в представленій статті метою $є$ з'ясування сутності та значення документальної обгрунтованості проведення документів фінансово-кредитних операцій і відображення їх в обліку підприємства для експертного дослідження документів фінансово-кредитних операцій.

Виклад основного матеріалу. Висвітлення окресленої проблематики вважаємо за необхідне розпочати зі з'ясування змісту фінансово-кредитних операцій і основних вимог до них. Так, фінансово-кредитні операції є різновидом фінансових послуг - операцій з фінансовими активами, що здійснюються в інтересах третіх осіб за власний рахунок чи за рахунок цих осіб, а у випадках, передбачених законодавством, - i за рахунок залучених від інших осіб фінансових активів, з метою отримання прибутку або збереження реальної вартості фінансових активів. Фінансово-кредитні операції полягають в наданні в позику юридичній або фізичній особі коштів на визначений строк та під процент. При цьому надавати фінансові кредити за рахунок залучених коштів має право на підставі відповідної ліцензії лише кредитна установа. Окрім того, фінансова установа зобов'язана вести облік своїх операцій та надавати звітність відповідно до вимог законів та нормативно-правових актів органів, які здійснюють державне регулювання ринків фінансових послуг [2].

Більше того, фінансово-кредитні операції є й різновидом діяльності банку, тобто банківських послуг. Зокрема, в ст. 339 ГК України зазначається, що фінансове посередництво здійснюється банками у формі банківських операцій. Основними видами банківських операцій $є$ депозитні, розрахункові, кредитні, факторингові та лізингові операції [3]. Тобто кредитні операції $є$ різновидом банківських операцій. При цьому в п. 3 ч. 3 ст. 47 і ч. 1 ст. 49 закону України «Про банки і банківську діяльність» закріплено, що як кредитні операції розглядаються: розміщення залучених у вклади (депозити), у тому числі на поточні рахунки, коштів та банківських металів від свого імені, на власних умовах та на власний ризик; здійснення операцій на ринку цінних па- 
перів від свого імені; надання гарантій і поручительств та інших зобов'язань від третіх осіб, які передбачають їх виконання у грошовій формі; придбання права вимоги на виконання зобов'язань у грошовій формі за поставлені товари чи надані послуги, приймаючи на себе ризик виконання таких вимог та прийом платежів (факторинг); лізинг [4].

Разом із тим, у фаховій літературі можна зустріти наступні підходи до визначення фінансово-кредитних операцій. Зокрема, Т.О. Крівцова, досліджуючи сутність кредитних операцій, констатувала, що на законодавчому рівні, згідно Інструкції з бухгалтерського обліку кредитних, вкладних (депозитних) операцій та формування і використання резервів під кредитні ризики в банках України, кредитні операції (кредит) - вид активних операцій, пов’язаних з наданням клієнтам коштів у тимчасове користування або прийняттям зобов'язань про надання коштів у тимчасове користування за певних умов, а також надання гарантій, поручительств, авалів, розміщення депозитів, проведення факторингових операцій, фінансового лізингу, видача кредитів у формі врахування векселів, у формі операцій репо, будь-яке продовження строку погашення боргу, яке надано в обмін на зобов'язання боржника щодо повернення заборгованої суми, а також на зобов'язання на сплату відсотків та інших зборів з такої суми (відстрочення платежу) [5, с. 257].

При цьому фінансово-кредитні операцій є нічим іншим, як правочином, який в обов'язковому порядку укладається в письмовій формі, що в свою чергу означає, що вони завжди документально зафіксовані. Тобто кредитні відносини здійснюються на підставі кредитного договору [3]. Кредитний договір укладається між кредитором і позичальником у письмовій формі. За ним банк або інша фінансова установа (кредитодавець) зобов'язується надати грошові кошти (кредит) позичальникові у розмірі та на умовах, встановлених договором, а позичальник зобов'язується повернути кредит та сплатити проценти (ст. ст. 1054, 1055 ЦК України) [6]. Окрім того, умови та порядок здійснення фінансово-кредитних операцій, а також їх наслідки знаходять своє відображення в обліково-звітній документації. Як приклад, фінансова звітність - звітність, що містить інформацію про фінансовий стан та результати діяльності підприємства. Метою ведення бухгалтерського обліку і складання фінансової звітності є надання користувачам для прийняття рішень повної, правдивої та неупередженої інформації про фінансовий стан та результати діяльності підприємства. При цьому обліково-звітна інформація про фінансовий стан і результати діяльності підприємства є взаємозалежною, оскільки фінансова, податкова, статистична та інші види звітності, що використовують грошовий вимірник, грунтуються на даних бухгалтерського обліку [7].

3 вищенаведеного помітно, що фінансово-кредитні операції, будучи різновидом фінансових послуг, повинні бути документально обгрунтованими, а тому під час доказування у справах про правопорушення, пов'язані з фінансово-кредитними операціями, особлива увага приділяється пошуку та дослідженню документів таких операцій. Зокрема, особливу роль в цій діяльності відіграє такий різновид судової експертизи як судова економічна експертиза документів фінансово-кредитних операцій. Останню нерідко в наукових працях іменують як фінансово-кредитну операцію.

На важливість і необхідність дослідження документів під час проведення судово-економічних експертиз неодноразово в своїх працях указують науковці. Зокрема, Я.І. Мулик зазначає, що дослідження в сфері економічної експертизи базуються на вивченні господарської діяльності особи, процесі формування фінансових показників за здійсненими операціями та правильності відображення їх в обліку. Відповідно проведення економічної експертизи дозволяє зафіксувати документальне підтвердження відповідності звітності по фінансово-господарським операціям податковому кодексу та чинному законодавству України [8, с. 29-30]. У цьому контексті вбачається вірним твердження, висловлене О.В. Сіренко, згідно з яким предметом фінансово-кредитної експертизи є відображені в документах господарські операції банків і підприємств при взаємовідносинах з банками, що стали об'єктом розгляду судово-слідчими органами, відносно яких поставлені питання на вирішення експерта [9, с. 515; 10, с. 408]. Іншими словами, предметом указаної судової експертизи є відображена в документах інформація щодо фінансово-економічних показників діяльності підприємства, акціонування, банкрутства, орендних відносин, цільового використання бюджетних коштів, які стали об'єктом розгляду судово-слідчими органами і відносно яких поставлені питання на вирішення експерта [11, с. 204].

Як відомо, предмет будь-якої експертизи, в тому числі судової економічної експертизи документів фінансово-кредитних операцій, є сукупністю питань, на які судовий експерт за допомогою наявних і апробованих методів, засобів і методик повинен дати відповідь для вирішення завдань відповідної судової експертизи. Зокрема, в Науково-методичних рекомендацій з питань підготовки та призначення судових експертиз та експертних досліджень зазначається, що ос- 
новними завданнями експертизи документів фінансово-кредитних операцій є визначення: документальної обгрунтованості оформлення банківських операцій з відкриття рахунків, руху грошових коштів на рахунках; документальної обгрунтованості оформлення та відображення в обліку операцій з видачі, використання та погашення кредитів; документальної обгрунтованості оформлення та відображення в обліку банків їх фінансово-господарської діяльності; відповідності відображення фінансово-господарських операцій банків вимогам нормативних актів з ведення обліку і подання звітності; документальної обгрунтованості відображення фінансово-господарських операцій щодо нарахування та сплати банками податків та їх відповідності даним обліку та звітності, чинному законодавству; документальної обгрунтованості проведення операцій за депозитними вкладами у банківських та інших фінансових установах [12]. Тобто основні завдання судової економічної експертизи документів фінансово-кредитних операцій зводяться до визначення їх документальної обгрунтованості.

Ось чому, висвітлюючи теоретичні та загально-методичні положення судової економічної експертизи документів фінансово-кредитних операцій, важливо визначити сутність і значення документальної обгрунтованості фінансово-кредитних операцій, а також їх відображення їх в обліку підприємства.

Говорячи про документальну обгрунтованість фінансово-кредитних операцій, мова йде передусім про те, що всі умови здійснення вказаних операцій у повному обсязі та безперервно повинні фіксуватися в документах бухгалтерського обліку та фінансової звітності. При цьому фактичні умови та процедура здійснення фінансово-кредитних операцій повинна відповідати тим, що закріплені документально. У такому разі кожна зі сторін може забезпечити захист своїх прав і у випадку їх порушення, використовуючи правові інструменти, поновити їх і відшкодувати збитки, завдані правопорушеннями, пов'язаними з фінансово-кредитними операціями.

Характерним для бухгалтерського фінансового обліку, як зазначає авторський колектив, $\epsilon$ те, що він будується на суцільному і безперервному спостереженні за подіями суб'єкта господарювання і процесами, що відбуваються на підприємстві. Для проведення такого первинного спостереження кожний господарський факт або процес необхідно оформити відповідним первинним документом (доказом). При цьому можуть використовуватися одні й ті самі елементи методу бухгалтерського обліку: документація, інвентаризація, оцінка, калькуляція, рахунки, подвійний запис, баланс, але неоднаковою мірою з огляду на властивість облікованих об'єктів [13, с. 30]. 3 наведеного помітно, що документування облікової інформації про фінансово-кредитні операції $\epsilon$ одним із способів управління та контролю за сферою кредитування. Адже облік підприємства полягає в формуванні своєчасної, повної й достовірної інформації про здійснені господарські операції суб'єктом господарювання, зокрема фінансово-кредитні, а також забезпеченні користувачів інформацією для контролю за правильністю оформлення банківських операцій з відкриття рахунків, руху грошових коштів на рахунках; правильністю оформлення та повнотою відображення в обліку операцій з видачі, використання та погашення кредитів; правильністю оформлення та повнотою відображення в обліку банків їх фінансово-господарської діяльності й ïx відповідності вимогам нормативних актів з ведення обліку і подання звітності; повнотою відображення фінансово-господарських операцій щодо нарахування та сплати банками податків та їх відповідності даним обліку та звітності, чинному законодавству; проведенням операцій за депозитними вкладами у банківських та інших фінансових установах [13, с. 31; 12], та ії відображенні в обліково-звітній документації для узагальнення даних про діяльність суб'єкта господарювання, його фінансово-майновий стан і фінансові результати [13, с. 31].

Щоб фінансово-кредитні операції вважалися документально обгрунтованими, вся інформація про вказані операції повинна виражатися в документах обліку підприємства - бухгалтерському обліку, фінансовій, податковій, статистичній та інших видах звітності. Причому обліково-звітна документація підприємства взагалі та про фінансово-кредитні операції зокрема повинна грунтуватися на таких принципах, як: повне висвітлення; автономність; послідовність; безперервність; нарахування; превалювання сутності над формою; єдиний грошовий вимірник; інші принципи, визначені міжнародними або національними стандартами. Відповідно з урахуванням наведених принципів бухгалтерського обліку та фінансової звітності документація фінансово-кредитних операцій повинна містити всю інформацію про фактичні та потенційні наслідки фінансово-кредитних операцій та подій здатних вплинути на рішення, що приймаються на її основі; відображати доходи і витрати підприємства в момент їх виникнення, незалежно від дати надходження або сплати грошових коштів; обліковувати операції відповідно до їх сутності, а не лише виходячи з юридичної форми; оформлюватися із постійним застосуванням підприємством 
обраної облікової політики; тощо [7]. Тож під час проведення судової експертизи документів фінансово-кредитних операцій з метою вирішення такого основного завдання вказаної експертизи як встановлення документальної обгрунтованості фінансово-кредитних операцій обов'язковому дослідженню підлягають первинні документи, реєстри бухгалтерського обліку, фінансова звітність, інші документи, пов'язані зі здійсненням фінансово-кредитних операцій.

Виходячи з наведених раніше завдань судової експертизи документів фінансово-кредитних операцій, об'єктами такого дослідження є договори про надання фінансових кредитів та інші документи, пов'язані з наданням таких кредитів. Насамперед мова йде про первинні документи документи, які містять відомості про господарську операцію, в досліджуваному випадку про фінансово-кредитну операцію, і підтверджує ії здійснення [7]. Тобто будь-які документи (зокрема договори, накладні, акти, рахунки тощо) мають силу первинних документів лише в разі фактичного здійснення господарської операції [13, с. 29]. Окрім первинних документів, для проведення судової експертизи документів фінансово-кредитних операцій надаються обліково-звітні й інші документи, пов'язані з фінансово-кредитними операціями.

Відповідно об'єктами такої судової експертизи є: кредитний договір з усіма додатками до нього; додаткові угоди до кредитного договору (у разі їх наявності); договори страхування, застави, іпотек, тощо та додаткові угоди до них, які укладені для забезпечення умов кредитного договору; договори на обслуговування банківського рахунку; документальне підтвердження наданої позичальнику інформації про умови кредитування, а також орієнтовану сукупну вартість кредиту; графік погашення платежів або детальний розрахунок щомісячного платежу позичальника за кредитним договором; деталізований розрахунок суми всіх видів заборгованості позичальника по кредиту, відсоткам, пені, штрафу, з вказівкою періодів нарахування та проведення сплати відповідачем відповідних платежів, згідно яких вбачаються терміни прострочення відповідних грошових зобов'язань, згідно умов кредитного договору; детальна розшифровка сукупної вартості кредиту і реальної процентної ставки за ним, абсолютного подорожчання кредиту, з урахуванням вартості всіх супутніх послуг, а також інших фінансових зобов'язань споживача, які виникають на користь третіх осіб згідно з вимогами законодавства України при видачі кредиту; платіжні та касові документи, що підтверджують видачу кредиту; платіжні та касові документи, що підтверджують погашення заборгованості за кредитним договором (основного та простроченого боргу по кредиту, строкових та прострочених процентів, комісії, тощо); первинні документи, що підтверджують надання позичальнику банком супутніх послуг з урахуванням їх вартості, процентної ставки за ними, а також будь яких інших фінансових зобов'язань споживача, які пов'язані з отриманням, обслуговуванням та погашенням кредиту; первинні документи, що підтверджують сплату позичальником вартості супутніх витрат і фінансових зобов'язань на користь третіх осіб, пов'язані з отриманням кредиту (страхові платежі під час страхування предмета застави, розмір зборів до Пенсійного фонду України, комісії під час купівлі - продажу іноземної валюти для погашення кредиту та процентів за користування ним, біржові збори, послуги реєстраторів, нотаріусів, інших осіб тощо), які чинять безпосередній вплив на подорожчання кредиту; виписки по всім розрахунковим рахункам, відкриті банком для обслуговування кредиту за кредитним договором; реєстри аналітичного та синтетичного бухгалтерського обліку по обліку виданих кредитів та нарахованих процентів, а також по поверненню суми кредиту і сплаті процентів; розпорядження банку (бухгалтерії за підписом керуючого банком, начальника кредитного відділу та ін.) про видачу кредиту, про пролонгацію кредиту, тощо; статистична звітність банку, стосовно кредитування; статутні та реєстраційні документи банку; банківські ліцензії та дозволи Національного банку України на здійснення операцій, у тому числі з валютними цінностями; внутрішні нормативні документи банку, що регламентують виконання конкретних технологічних процесів, документування операцій, ведення регістрів аналітичного й синтетичного обліку, процедури внутрішнього контролю операційної діяльності, у т. ч. положення про операційну діяльність, положення про облікову політику, а також методологію та процедури з бухгалтерського обліку, що цю політику регламентують, положення про кредитування, внутрішні положення банку, що визначають політику з управління активами та пасивами, відповідно до яких було надано кредитні кошти за кредитним договором, та інші внутрішні положення банку, що регламентують порядок надання та обслуговування кредитів, механізм розрахунку реальної процентної ставки, дисконтування платежів, обчислення платежів, методологічне обгрунтування погашення кредиту, внутрішні положення банку про проведення розрахунково - касових операцій з фізичними особами, методологічне обгрунтування визначення валютного курсу, строків і комісій, пов'язаних з конвертацією валюти платежу у валюту зобов'язання під час погашення заборгованості за 
кредитом та процентами за користування ним (у разі надання кредиту у валюті) [14]. При цьому всіма додатками до кредитного договору є всі ті документи, які позичальник надає кредиторові, а також ті документи, що містять інформацію, яку кредитодавець зобов'язаний додатково надати клієнтові до укладання з ним договору про надання фінансової послуги.

Висновки. Отже, документальна обгрунтованість фінансово-кредитних операцій - це безперервне та повне фіксування інформації про здійснені фінансово-кредитні операції в обліково-звітній документації для узагальнення даних про діяльність суб'єкта господарювання та його фінансовий стан. Документування облікової інформації про фінансово-кредитні операції $\epsilon$ одним із способів управління та контролю за сферою кредитування. Зокрема, облік підприємства дозволяє встановити правильність оформлення банківських операцій з відкриття рахунків, руху грошових коштів на рахунках; правильність оформлення та повноту відображення в обліку операцій з видачі, використання та погашення кредитів; правильність оформлення та повноту відображення в обліку банків їх фінансово-господарської діяльності й їх відповідності вимогам нормативних актів з ведення обліку і подання звітності; повноту відображення фінансово-господарських операцій щодо нарахування та сплати банками податків та їх відповідність даним обліку та звітності, чинному законодавству; правильність проведення операцій за депозитними вкладами у банківських та інших фінансових установах [12]. Визначення документальної обгрунтованості фінансово-кредитних операцій, як основного завдання судової економічної експертизи документів фінансово-кредитних операцій, полягає в дослідженні первинних документів, реєстрів бухгалтерського обліку, фінансової звітності, інших документів, пов'язаних із здійсненням фінансово-кредитних операцій і встановленні їх відповідності фактичним умовам здійснення фінансово-кредитних операцій і чинному законодавству України.

\section{Список використаних джерел:}

1. Економічна експертиза в кредитних спорах. Вісник НICE. 21 травня 2015 р. № 4.27 с.

2. Про фінансові послуги та державне регулювання ринків фінансових послуг: закон України від 12.07.2001 № 2664-III. Відомості Верховної Ради Украӥни. 2002. № 1. Стаття 1.

3. Господарський кодекс України: закон України від 16.01.2003 № 436-IV. Bidoмосmi Bepховної Ради України. 2003. № 18. Стаття 144.

4. Про банки і банківську діяльність: закон України від 07.12.2000 № 2121-III. Вiдомості Верховної Ради України. 2001. № 5. Стаття 30.

5. Крівцова Т.О. Сутність і зміст організації внутрішнього контролю кредитних операцій банку. Сталий розвиток економіки: міжнародний науково-виробничий журнал. 2015. № 1 (26). С. $256-262$.

6. Цивільний кодекс України: закон України від 16.01.2003 № 435-IV. Вiдомості Верховної Ради України. 2003. № 40. Стаття 356.

7. Про бухгалтерський облік та фінансову звітність в Україні: закон України від 16.07.1999 № 996-XIV. Відомості Верховної Ради України. 1999. № 40. Стаття 365.

8. Мулик Я.І. Економічна експертиза в Україні: теоретичні та практичні аспекти. Wschodnioeuropejskie Czasopismo Naukowe (East European Scientific Journal). 2020. № 2 (54). C. $27-38$.

9. Сіренко О.В. Застосування спеціальних знань при розслідуванні злочинів у фінансовій сфері. Управління публічними фінансами та проблемами забезпечення національної економічної безпеки: збірник тез податкового конгресу (12 грудня 2019 року, м. Ірпінь). Ірпінь: Ун-т держ. фіск. служби України, 2019. С. 514-516.

10. Вітер Д.В. Судово-економічна експертиза у доведенні обставин, що підлягають обов'язковому доказуванню при розслідуванні злочинів у сфері фінансування соціальних цільових програм. Теорія та практика судової експертизи і криміналістики. 2019. № 20. С. $403-414$. DOI: https://doi.org/10.32353/khrife.2.2019.31.

11. Експертизи у судочинстві України / за заг. ред. В.Г. Гончаренко, І.В. Гора. Бюлетень законодавства і юридичної практики. № 5-6. Київ: Юрінком-Інтер, 2015. 509 с.

12. Про затвердження Інструкції про призначення та проведення судових експертиз та експертних досліджень та Науково-методичних рекомендацій з питань підготовки та призначення судових експертиз та експертних досліджень: наказ Міністерства юстиції України від 08.10.1998 № 53/5, зареєстрований в Міністерстві юстиції України 03.11.1998 за № 705/3145. Oфiųiüнuй вісник Украӥни. 1998. № 46. Стор. 172. Стаття 1715. Код акта 6348/1998.

13. Облік і звітність підприємств у системі оподаткування: навч. посіб. / М.І. Бондар та ін.; за заг. ред. М.І. Бондаря, Н.М. Лисенко; передм. Т.І. Сфименко. К.: ДННУ «Акад. фін. управління», 2012. 584 с. 
14. Документи, що надаються для проведення експертизи фінансово-кредитних операцій за кредитними договорами, укладеними між Банками та Позичальниками-фізичними особами. ОНДІСЕ.URL:http://ondise.minjust.gov.ua/dokumenti-shho-nadayutsya-dlya-provedennya-ekspertizifinansovo-kreditnix-operacij-za-kreditnimi-dogovorami-ukladenimi-mizh-bankami-ta-pozichalnikamifizichnimi-osobami/.

УДК $347.965(477)$

DOI https://doi.org/10.32844/2618-1258.2020.3-2.47

CEBEPIHOBA О.Б.

\section{ПІДГОТОВКА КАДРІВ ЗБРОЙНИХ СИЛ У 1950-60-Х РОКАХ ХХ СТОРІЧЧЯ}

\section{TRAINING OF THE ARMED FORCES IN THE 1950-60-S OF THE XX CENTURY}

Актуальність статті полягає в тому, що широке впровадження в Збройні сили СРСР принципово нового зброї і військової техніки в 1950-1960-і рр. викликали необхідність перебудови системи підготовки кадрів, навчання і виховання військовослужбовців. Революція у військовій справі пред'явила нові вимоги до їх технічної підготовки та стилю роботи. При цьому враховувалося, що корінні зміни у військовій справі призвели до суттєвих зрушень в структурі офіцерського корпусу: помітно став зростати питома вага інженерів і техніків. Стаття присвячена дослідженню особливостей підготовки кадрів збройних сил у 1950-60-х роках ХХ сторіччя. Також в статті проаналізовано основні напрямки та підходи різних вчених щзодо вивчення вказаної проблематики. Друга половина 1950-х рр. характеризувалася активним пошуком найбільш ефективної системи підготовки авіаційних фахівців, здатних успішно вивчити і вміло застосовувати реактивну авіацію в умовах можливого використання ракетно-ядерної зброї. 3'ясовано, для підвищення технічних знань всіх категорій офіцерів багато середніх військові і військово-технічні училища перетворювалися в вищі військово-навчальні заклади. Особливу увагу в 1950-х рр. приділялася підготовці фахівців для частин, що забезпечували правильне зберігання і експлуатацію ядерної зброї. До 1954 року їх підготовка велася на піврічних курсах в чотирьох навчальних центрах. Радикального підвищення кваліфікації офіцерів, які експлуатували ядерну зброю, які контролювали його розробку і виробництво, сприяла що почалася підготовка таких фахівців у військових академіях. Зроблено висновок, що у розвитку системи підготовки військових кадрів Збройних Сил СРСР в 1953-1964 рр. чітко простежується два етапи. В ході першого з них - в 1953-1959 рр. здійснювалося планомірне розвиток системи військової освіти на тлі розгортається революції у військовій справі. Значущими подіями цього етапу стало створення військових навчальних закладів для підготовки офіцерів-ракетників, льотчиків вертолітної авіації, обслуговуючого персоналу атомних енергетичних установок підводних човнів і ядерних боєприпасів. У той же час цілі напрямки військової освіти (насамперед по тиловим спеціальностями) були фактично ліквідовані.

Ключові слова: Збройні сили, військово-службові відносини, кадри, підготовка кадрів.

The relevance of the article is that the widespread introduction into the Armed Forces of the USSR of fundamentally new weapons and military equipment in the 1950s and 1960s necessitated a restructuring of the system of training, education and upbringing of servicemen. The military revolution has placed new demands on their technical training 